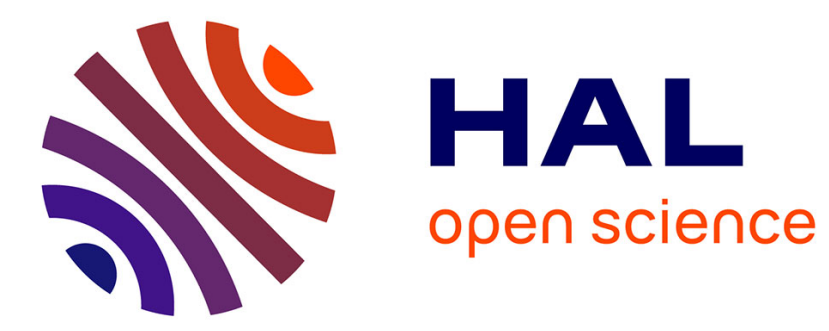

\title{
PPAR agonists reduce steatosis in oleic acid-overloaded HepaRG cells
}

\author{
Alexandra Rogue, Sébastien Anthérieu, Aurore Vluggens, Thierry \\ Umbdenstock, Nancy Claude, Catherine de La Moureyre-Spire, Richard J \\ Weaver, André Guillouzo
}

\section{To cite this version:}

Alexandra Rogue, Sébastien Anthérieu, Aurore Vluggens, Thierry Umbdenstock, Nancy Claude, et al.. PPAR agonists reduce steatosis in oleic acid-overloaded HepaRG cells. Toxicology and Applied Pharmacology, 2014, 276 (1), pp.73-81. 10.1016/j.taap.2014.02.001 . hal-01020611

\section{HAL Id: hal-01020611 \\ https://hal-univ-rennes1.archives-ouvertes.fr/hal-01020611}

Submitted on 8 Jul 2014

HAL is a multi-disciplinary open access archive for the deposit and dissemination of scientific research documents, whether they are published or not. The documents may come from teaching and research institutions in France or abroad, or from public or private research centers.
L'archive ouverte pluridisciplinaire HAL, est destinée au dépôt et à la diffusion de documents scientifiques de niveau recherche, publiés ou non, émanant des établissements d'enseignement et de recherche français ou étrangers, des laboratoires publics ou privés. 


\section{TITLE PAGE}

PPAR agonists reduce steatosis in oleic acid-overloaded HepaRG cells

Alexandra Rogue ${ }^{a, b, c, *}$, Sébastien Anthérieu ${ }^{a, b, *}$; Aurore Vluggens ${ }^{a, b}$, Thierry Umbdenstock ${ }^{\text {d }}$, Nancy Claude ${ }^{\mathrm{e}}$, Catherine de la Moureyre-Spire ${ }^{\mathrm{c}}$, Richard J. Weaver ${ }^{\mathrm{c}}$ and André Guillouzo ${ }^{\mathrm{a}, \mathrm{b}}$

${ }^{a}$ Inserm UMR 991, F-35043 Rennes cedex, France

${ }^{\text {b }}$ Université de Rennes 1, Faculté des Sciences Pharmaceutiques et Biologiques, 35043 Rennes cedex, France

${ }^{\mathrm{c}}$ Biologie Servier, Gidy, France

d Technologie Servier, Orléans, France

${ }^{\mathrm{e}}$ Institut de Recherches Servier, Courbevoie, France

* Both authors contributed equally to this work

\section{Corresponding author :}

$\underline{\text { Pr. André Guillouzo }}$

Inserm UMR 991

Faculté des Sciences Pharmaceutiques et Biologiques

35043 Rennes Cedex, France

Phone: +33 223234791

Fax: +33223235385

Email: Andre.Guillouzo@univ-rennes1.fr 


\section{FOOTNOTE PAGE}

\section{List of Abbreviations}

FAO: fatty acid oxidation; MTT: methylthiazoletetrazolium; NAFLD: non-alcoholic fatty liver diseases; NASH: non-alcoholic steatohepatitis; OA: oleic acid; PPAR: Peroxisome proliferator-activated receptor

\section{Financial Support}

This work was supported by International Research Servier Group (IRIS) and the European Community (Contracts Predict-IV-202222 and MIP-DILI-115336). The MIP-DILI project has received support from the Innovative Medicines Initiative Joint Undertaking, resources of which are composed of financial contribution from the European Union's Seventh Framework Programme (FP7/20072013) and EFPIA companies' in kind contribution. http://www.imi.europa.eu/

Disclosures: The authors declare no conflicts of interest 


\begin{abstract}
Although non-alcoholic fatty liver disease (NAFLD) is currently the most common form of chronic liver disease there is no pharmacological agent approved for its treatment. Since peroxisome proliferator-activated receptors (PPARs) are closely associated with hepatic lipid metabolism, they seem to play important roles in NAFLD. However, the effects of PPAR agonists on steatosis that is a common pathology associated with NAFLD, remain largely controversial. In this study, the effects of various PPAR agonists, i.e. fenofibrate, bezafibrate, troglitazone, rosiglitazone, muraglitazar and tesaglitazar on oleic acid-induced steatotic HepaRG cells were investigated after a single 24-hour or 2-week repeat treatment. Lipid vesicles stained by Oil-Red $\mathrm{O}$ and triglycerides accumulation caused by oleic acid overload, were decreased, by up to $50 \%$, while fatty acid oxidation was induced after 2-week cotreatment with PPAR agonists. The greatest effects on reduction of steatosis were obtained with the dual PPAR $\alpha / \gamma$ agonist muraglitazar. Such improvement of steatosis was associated with up-regulation of genes related to fatty acid oxidation activity and down-regulation of many genes involved in lipogenesis. Moreover, modulation of expression of some nuclear receptor genes, such as FXR, LXR $\alpha$ and CAR, which are potent actors in the control of lipogenesis, was observed and might explain repression of de novo lipogenesis. Conclusion: Altogether, our in vitro data on steatotic HepaRG cells treated with PPAR agonists correlated well with clinical investigations, bringing a proof of concept that drug-induced reversal of steatosis in human can be evaluated in in vitro before conducting long-term and costly in vivo studies in animals and patients.
\end{abstract}

Key words: hepatotoxicity; non-alcoholic steatohepatitis; fatty acid oxidation; fatty acid overload; hepatocytes 


\section{INTRODUCTION}

Non-alcoholic fatty liver disease (NAFLD) is currently the most common form of chronic liver disease and is strongly associated with obesity, type 2 diabetes and insulin resistance (Caldwell and Argo, 2010 ; Lomonaco et al., 2013). Considered as the hepatic manifestation of the metabolic syndrome, NAFLD encompasses a wide spectrum of clinical-histological disturbances ranging from simple triglycerides accumulation in hepatocytes (hepatic steatosis) to hepatic steatosis with inflammation [non-alcoholic steatohepatitis (NASH)], fibrosis, cirrhosis and in severe cases, hepatocarcinoma.

The pathogenesis of fatty liver is intimately related to derangements in nutrient metabolism and energy homeostasis, which are tightly regulated by endocrine, paracrine, and autocrine signals that control the expression and activity of key metabolic enzymes by transcriptional and post-transcriptional mechanisms. Peroxisome proliferator-activated receptors (PPARs) have recently emerged as a master class of ligand-activated transcription factors involved in maintaining lipid homeostasis and energy balance, as well as a variety of other biological processes. PPARs comprise three subtypes: PPAR $\alpha$ (NR1C1), PPAR $\beta / \delta$ (NR1C2) and PPAR $\gamma$ (NR1C3), that each mediates distinct physiological effects on lipid metabolism and glucose homeostasis (Michalik et al., 2006). PPAR $\alpha$ plays a pivotal role in fatty acid catabolism in liver by transcriptionally up-regulating the expression of some of the key genes involved in fatty acid oxidation (FAO) (Reddy and Hashimoto, 2001). PPAR $\beta / \delta$ is a powerful metabolic regulator expressed ubiquitously that also exerts key functions in liver by enhancing fatty acid catabolism (Barish et al., 2006). PPAR $\gamma$ is mainly expressed in adipose tissue and is known to be a regulator of lipid metabolism and glucose homeostasis.

Synthetic PPAR agonists represent attractive drug targets for the management of NAFLD and NASH. PPAR $\alpha$ activators, typified by fibrates, are used to treat dyslipidemia while PPAR $\gamma$ ligands, such as thiazolidinediones, act as insulin sensitizers in type 2 diabetes mellitus. Both agonist classes have been reported to attenuate NASH. Thus, fibrates, such as fenofibrate, have been shown to reduce and/or prevent fatty liver in various experimental models (Nagai et al., 2002; Ye et al., 2002). Their effects have been attributed to an increase in hepatic FAO activity, however some discrepancies have been observed in human NASH treated with fibrates. A 12-month treatment of patients with NASH and elevated triglycerides with 
clofibrate had no impact on liver enzyme elevation or triglyceride levels (Laurin et al., 1996). In fact, the human liver expresses relatively low levels of PPAR $\alpha$ and PPAR $\alpha$ activation, and has little impact on FAO in contrast to its rodent counterpart (Kane et al., 2006). The PPAR pan-agonist, bezafibrate, which modulates FAO by influencing both PPAR $\alpha$ and PPAR $\delta$, was also found to reduce hepatic steatosis (Nagasawa et al., 2006) and improve NASH (Nagasawa et al., 2006; Lim et al., 2009).

The effects of PPAR $\gamma$ agonists on steatosis and NAFLD are also controversial. While PPAR $\gamma$ expression and activity are low in normal liver they are usually increased in steatotic liver of both animals (Kim et al., 1998) and humans (Gavrilova et al., 2003). Nevertheless, although PPAR $\gamma$ is considered as a steatogenic factor, its activation is a putative target for the treatment of NAFLD. Indeed, thiazolidinediones (e.g. pioglitazone and rosiglitazone) and metformin are the principal insulin sensitizing agents employed in the management of NAFLD for their capacity to reduce amino-transferase levels and to improve histological grading (Balas et al., 2007), probably as a consequence of their primary insulin-sensitizing effects on adipose tissue (Tanaka et al., 2003).

Dual PPAR $\alpha / \gamma$ agonists have also been considered to be attractive as therapy for NAFLD, NASH and the metabolic syndrome as they have been reported to have the potential to improve insulin sensitivity and decrease circulating triglycerides in animals. However, the first molecules, muraglitazar and tesaglitazar, have been withdrawn from phase III clinical trials due to increased incidence of cardiac and renal toxicities (Hamren et al., 2008; Rubin et al., 2009).

With the global prevalence of metabolic syndrome, obesity and NAFLD in recent years, there is an increasing need to better understand the role of PPAR agonists on the etiology of fatty liver disease. The aim of this study was to analyze the effects of the different types of PPAR agonists (glitazones, glitazars and fibrates) on steatosis induced by oleic acid overload in differentiated human HepaRG cells after acute and repeat treatments (Antherieu et al., 2011). A decrease in triglycerides content associated with an increase in FAO-related gene expression and activity was observed with all agonists after 14-day repeat exposure. The strongest effects were obtained after treatment with the dual PPAR $\alpha / \gamma$ agonist muraglitazar. 


\section{MATERIAL AND METHODS}

Chemicals. Troglitazone, rosiglitazone, muraglitazar and tesaglitazar were provided by the Servier Chemical Department. Fenofibrate, bezafibrate and oleic acid (OA) were purchased from Sigma (St. Quentin Fallavier, France). $\left[\mathrm{U}_{-}{ }^{14} \mathrm{C}\right]$-palmitic acid was from Perkin Elmer (Boston, MA).

HepaRG cells. The untransformed human HepaRG cell line is derived from a human cholangiohepatocarcinoma. The cells used in this study were from cells stored frozen at passage 10 and experiments were performed between passages 13 and 18. Briefly, HepaRG cells were usually seeded at a density of $2.6 \times 10^{4}$ cells $/ \mathrm{cm}^{2}$ in the Williams' E medium supplemented with $10 \%$ fetal calf serum, 100 units $/ \mathrm{mL}$ penicillin, $100 \mu \mathrm{g} / \mathrm{mL}$ streptomycin, 5 $\mu \mathrm{g} / \mathrm{mL}$ insulin, $2 \mathrm{mM}$ glutamine and $50 \mu \mathrm{M}$ hydrocortisone hemisuccinate (Gripon et al., 2002). After two weeks, HepaRG cells were transferred to the same medium supplemented with 2\% dimethylsulfoxide (DMSO) for further two weeks in order to obtain confluent differentiated cultures containing both hepatocyte-like and progenitors/primitive biliary-like cells (around 50\% of each type) (Cerec et al., 2007). In the presence of DMSO the levels of certain functions, in particular those of some major cytochromes P450 such as CYP3A4, are markedly increased (Aninat et al., 2006; Kanebratt and Andersson, 2008; Antherieu et al., 2010).

Chemical treatments. The PPAR agonists and OA were dissolved manually in dimethylsulfoxide. HepaRG cell cultures were first exposed to $250 \mu \mathrm{M}$ OA for 24 hours, then continuously to OA either alone or together with each PPAR agonist for 24 hours or repeated treatments every 2-3 days for 14 days (Figure 1). DMSO dilutions were made from a 100\% DMSO solution. At least three independent experiments were performed in triplicates.

Cell viability. Cytotoxicity was evaluated using the methylthiazoletetrazolium (MTT) colorimetric assay. After treatment, medium was removed and serum-free medium containing $0.5 \mathrm{mg} / \mathrm{mL}$ MTT was added to each well and incubated for 2 hours at $37^{\circ} \mathrm{C}$. After removal of the incubation solution, water-insoluble formazan was dissolved in DMSO and absorbance was measured at $550 \mathrm{~nm}$.

Oil Red $O$ staining and lipid droplets analysis by cell imaging. Neutral lipid accumulation was determined by Oil Red O staining, which allows detection of triglycerides and cholesterol esters. A stock solution of Oil Red O was prepared in isopropanol (0.5:100). After each 
treatment, cells were incubated for one hour with Oil Red O-saturated solution (isopropanol:water, 3:2) and then observed under phase-contrast microscopy. To quantify lipid accumulation, Oil Red O-stained lipid droplets were analyzed by cell imaging. Areas of stained droplets were determined by the Image $\mathrm{J}$ software and normalized by the areas of hepatocyte clusters.

Triglycerides quantification. Triglycerides were extracted using an organic solvent chloroform/methanol (2/1 v/v). A serum triglycerides determination kit (Sigma) was used for quantification, using a spectrophotometer with absorbance at $550 \mathrm{~nm}$ according to the manufacturer's instructions.

Real time-quantitative polymerase chain reaction analysis (RT-qPCR). Total RNA was extracted from $10^{6}$ HepaRG cells using the SV total RNA isolation system (Promega). RNAs were reverse-transcribed into cDNA and RT-qPCR was performed using a SYBR Green mix and a Step One plus equipment (Applied Biosystems). Primer sequences are listed in Table 1.

Fatty acid oxidation. HepaRG cells were incubated with a medium containing $0.5 \mathrm{mM} \mathrm{L}-$ carnitine, $10 \%$ fat-free bovine serum albumin and $\left[\mathrm{U}_{-}{ }^{14} \mathrm{C}\right]$-palmitic acid (final concentration, $1 \mathrm{mM} ; 0.05 \mu \mathrm{Ci} / \mathrm{mL}$ ). The reaction was carried out for $90 \mathrm{~min}$ at $37^{\circ} \mathrm{C}$. After addition of perchloric acid (final concentration, $3 \%$ ) and centrifugation $(4000 \mathrm{~g} ; 10 \mathrm{~min}$ ) an aliquot of the supernatant was sampled and counted for $\left[{ }^{14} \mathrm{C}\right]$-labelled acid-soluble $\beta$-oxidation products (Fisch et al., 1996).

Statistical analysis. Each value corresponded to the mean \pm standard error of mean (S.E.M) of three independent experiments in triplicates. The Mann-Whitney $U$ test was applied to compare data between OA- or drug-treated cell cultures and their control counterparts. Data were considered significantly different when $p<0.05$. 


\section{RESULTS}

\section{Cytotoxic effects of PPAR agonists in steatotic HepaRG cells}

Preliminary experiments were performed to assess cytotoxicity of the different PPAR agonists in steatotic HepaRG cells over a 14-day period. In order to induce vesicular steatosis, HepaRG cells were exposed to $250 \mu \mathrm{M}$ OA for 24 hours (Antherieu et al., 2011) prior to cotreatment with PPAR agonists. Noticeably, when OA-overloaded HepaRG cells were maintained in culture without repeat exposure to the fatty acid, vesicular steatosis disappeared within 5 days; consequently effects of PPAR agonists were investigated with simultaneous addition of OA during the 14-day treatment.

Neither cellular morphological alterations nor loss of cell viability were observed in untreated cultures over a 14- day period. OA alone did not cause any cytotoxicity after 1-day exposure while after a 14-day treatment slight toxicity was observed not exceeding a $12 \%$ decrease in MTT values. All compounds were added to the cultures at a high concentration corresponding to IC10, i.e. the concentration that caused $10 \%$ loss of cell viability in OAoverloaded HepaRG cells after 14-day treatment (Figure 2). Accordingly, examination of the cultures under phase-contrast microscopy did not reveal marked cellular morphological alterations after a 14-day treatment whatever the PPAR agonist tested. Consequently, $25 \mu \mathrm{M}$ fenofibrate and bezafibrate, $40 \mu \mathrm{M}$ troglitazone, $50 \mu \mathrm{M}$ rosiglitazone and muraglitazar and $300 \mu \mathrm{M}$ tesaglitazar were used for further experiments.

\section{Oil Red $O$ staining and quantification of lipid droplets by cell imaging}

Cells were first exposed to OA for $24 \mathrm{~h}$ and then co-treated with troglitazone, rosiglitazone, muraglitazar, tesaglitazar, fenofibrate and bezafibrate for either 1 or 14 days and neutral lipids (triglycerides and cholesterol esters) were stained by Oil Red O. Cells were examined under phase-contrast microscopy and photographed (Figure 3A) before quantification of intracellular Oil Red $\mathrm{O}$ accumulation by cell imaging (Figure 3B). As previously reported (Antherieu et al., 2011), numerous vesicles stained with Oil Red O were observed in the cytoplasm of HepaRG hepatocytes after 1- and 14-day incubation with OA under light microscopy. After 1-day co-treatment with PPAR agonists, intracellular distribution of lipid vesicles was not affected while their intracytoplasmic surface appeared to be reduced by about 
$50 \%$ after 14 days with rosiglitazone, muraglitazar, tesaglitazar, fenofibrate and bezafibrate. By contrast, troglitazone did not cause detectable variations in intracytoplasmic lipid staining when compared with cultures incubated with OA alone.

\section{Triglycerides quantification}

Triglycerides levels were determined by spectrophotometry (Figure 4). OA induced a 2-fold increase in triglycerides after 1 day and no further change was observed over a 14-day period. Co-treatment with PPAR agonists for 1 day did not show significant difference compared to untreated OA-overloaded cells. After repeat exposure, a slight decrease in triglycerides content was observed with troglitazone whereas more pronounced reduction was demonstrated with the other PPAR agonists, especially rosiglitazone and muraglitazar. Indeed, rosiglitazone and muraglitazar decreased triglycerides levels to approximately 50 and $60 \%$ of the values measured in the OA-treated cultures respectively.

\section{Induction of fatty acid oxidation}

Since FAO was described as an important pathway involved in the modulation of steatosis, the effects of PPAR agonists on FAO activity were also assessed (Figure 5). Cells were incubated with $\left[{ }^{14} \mathrm{C}\right]$-palmitate and FAO was estimated by measuring $\left[{ }^{14} \mathrm{C}\right]$-labelled acidsoluble ß-oxidation products. OA overload did not significantly modulate FAO activity whatever the treatment duration. No effect of PPAR agonists was also noticed after 1-day treatment. By contrast, FAO activity was increased after 14-day repeat treatment with all PPAR agonists. The highest increases were obtained with muraglitazar, bezafibrate and rosiglitazone, reaching 1.7-fold with muraglitazar relative to untreated control. In addition, a dose-response analysis of the effects of rosiglitazone and muraglitazar on fatty acid oxidation activity was performed and demonstrated that the highest effects were obtained with the highest concentration of each agonist (data not shown).

\section{mRNA expression modulation of key genes involved in lipid metabolism}

In order to better investigate the mechanisms involved in steatosis reduction in OAoverloaded HepaRG cells, changes in the expression of several genes, which are key players in lipid metabolism were examined by RT-qPCR after 1- and 14-day treatments with PPAR 
agonists (Table 2). These genes are involved in de novo lipogenesis (ELOVL6, FASN, PPARG, SCD1, SREBP1 and THRSP), FAO and mitochondrial biogenesis (ACADL, ACOX1, CPT1A, CPT2, ECH1, CYP4A11, HADHA and PPARA), lipid hydrolysis and formation of lipid droplets (ADFP, PLIN4 and LPL), lipoprotein synthesis (APOC3), nuclear receptors (LXR, FXR, PXR and CAR) as well as other liver functions (ALB and CYP2B6).

As previously reported, CTP1A, ADFP and PLIN4 were overexpressed and THRSP was repressed after 1-day and 14-day OA-overload (Antherieu et al.,2011). Almost all genes were modulated by one or more PPAR agonists at least at one time-point after 1- and 14-day cotreatments with OA. A noticeable up-regulation of the genes related to FAO, mitochondrial biogenesis, lipid hydrolysis and formation of lipid droplets was observed after 1-day treatment, with the highest fold changes after muraglitazar exposure, especially for ACOX1, CPT1A, CPT2, ECH1, ADFP and PLIN4. After 14-day treatment, expression of these genes remained most important for muraglitazar and rosiglitazone. Deregulated genes related to de novo lipogenesis, except THRSP, were also overexpressed after 1 day whereas they were mostly unchanged or even decreased after 14 days, for each PPAR agonist. It is noteworthy that APOC3, the main endogenous inhibitor of LPL, was overexpressed by rosiglitazone and the two glitazars after 14-day treatment.

To understand how modulation of related FAO and de novo lipogenesis genes might occur, expression of some nuclear receptors, such as LXR, FXR, PXR and CAR, were also investigated. After 1 day, LXR $\alpha$, the main inducer of SREBP1, was overexpressed by all the test compounds, especially the two glitazones. By contrast, after 14 days, LXR $\alpha$ expression was dramatically decreased by fenofibrate, troglitazone and tesaglitazar. The second isoform LXR $\beta$ did not show any significant change after either 1- or 14-day treatments (data not shown). The nuclear receptor FXR was also up-regulated after 1 day by bezafibrate and muraglitazar and it was still significantly overexpressed after 14 days by muraglitazar only.

PXR and CAR mRNA levels were similarly measured, because of their potential role in the regulation of lipid metabolism. After 1-day or 14 days treatments PXR expression was either unchanged or slightly down- or up-regulated. CAR expression was up-regulated after 1 day by both glitazones, fibrates, and muraglitazar whereas after 14 days, it was still deregulated only by muraglitazar, with a 2.2 -fold increase relative to untreated control.

ALB and CYP2B6 genes were also found to be modulated. After a 14-day treatment albumin transcripts were augmented with both glitazones and glitazars while they were decreased by 
fenofibrate and bezafibrate. As expected (Rogue et al.,2011), CYP2B6 was specifically overexpressed by the two glitazones at both time-points. 


\section{DISCUSSION}

Although NAFLD is currently the most common form of chronic liver disease there is currently no marketed drug for its treatment (Lomonaco et al., 2013). As PPAR agonists influence hepatic lipid homeostasis and energy balance, they represent an attractive target for the development of novel drug therapies in the management of NAFLD. However, although activation of the three classes of PPARs by synthetic ligands has been shown to reduce hepatic steatosis in rodents, discrepancies still remain with data obtained from clinical studies in humans (Laurin et al., 1996; Mahady et al., 2011; Lomonaco et al., 2013). In the current work, we showed that repeat activation of PPARs by several agonists resulted in reduction of steatosis using fatty acid-overload human HepaRG cells (Antherieu et al., 2011). Improvement of OA-induced steatosis was evidenced by a decrease in intracellular lipid droplets and triglycerides content, induction of FAO and overexpression of genes related to FAO and mitochondrial biogenesis after a 2-week treatment. The most potent effects were obtained with the dual PPAR agonist muraglitazar and to a lesser extent with rosiglitazone. The choice of PPAR agonists concentrations was based on IC10 values determined by the MTT test in 14-day cultures; such values are frequently used for functional studies in vitro. Thus, $25 \mu \mathrm{M}$ fenofibrate, $25 \mu \mathrm{M}$ bezafibrate, $40 \mu \mathrm{M}$ troglitazone, $50 \mu \mathrm{M}$ rosiglitazone, 50 $\mu \mathrm{M}$ muraglitazar and $300 \mu \mathrm{M}$ tesaglitazar represented around 1-, 8-, 50-, 35- and $>400$-fold the therapeutic concentrations respectively (Miller and Spence, 1998; Ericsson et al., 2004; Wang et al., 2006; Scheen, 2007).

Despite its relatively low expression level in the liver, PPAR $\gamma$ is thought to be critical in the development of hepatic steatosis (Desvergne et al., 2006). However, the role of PPAR $\gamma$ in NASH remains controversial. Indeed, this nuclear receptor is generally overexpressed in steatotic liver and has been reported to have a pro-steatogenic effect in both human and mouse hepatocytes (Moran-Salvador et al., 2011). Rosiglitazone was found to induce accumulation of neutral lipids, as detected by Oil Red O staining in the cytoplasm of primary hepatocytes isolated from control mice, an effect that was markedly amplified by association of rosiglitazone and OA (Moya et al., 2010; Moran-Salvador et al., 2011). By contrast, our results showed a reduction in steatosis in HepaRG cells after a 2-week treatment with rosiglitazone, which is in agreement with in vivo observations. Indeed, clinical studies have 
reported a reduction of steatosis after several months of treatment with rosiglitazone (Ratziu et al., 2008) and pioglitazone (Belfort et al., 2006). However, a systematic review and metaanalysis of the effects of thiazolidinediones have emphasized only their modest effect in the improvement of patients with NASH but at the cost of significant weight gain and other adverse events (Musso et al., 2010; Mahady et al., 2011). Taken altogether, such variable data could be explained by species differences, additional in vivo effects of glitazones in nonhepatic tissues and the use of different experimental conditions in vitro.

The dual PPAR $\alpha / \gamma$ agonists muraglitazar and to a lesser degree tesaglitazar, also ameliorated steatosis in HepaRG cells. Muraglitazar had even a stronger effect than rosiglitazone on the decrease in triglycerides content and induction of FAO, that could be related to its higher affinity for PPAR $\gamma$ (Fievet et al., 2006). Both glitazars have been reported to improve steatosis in vivo. A recent study on the effects of muraglitazar on glucose and lipid metabolism or fat distribution in patients has shown a beneficial effect on fat content, similar to that observed with pioglitazone (Fernandez et al., 2011). Tesaglitazar has been reported to ameliorate NAFLD in diabetic, low density receptor-deficient mice (Zhang et al., 2004) and to improve lipid profile in dyslipidemic patients (Tonstad et al., 2007). These two dual PPAR agonists were attractive as therapy for NASH and the metabolic syndrome. Unfortunately, due to cardiac or renal toxicities, muraglitazar and tesaglitazar were stopped during clinical trials. However, our results bring further support towards on-going development of new glitazars, such as cevoglitazar (Chen et al., 2010) and aleglitazar (Deehan et al., 2012).

Fenofibrate, a PPAR $\alpha$ agonist and bezafibrate, a PPAR pan-agonist, were also tested on steatotic HepaRG cells. In agreement with in vivo studies (Tonstad et al., 2007; Musso et al., 2010; Fernandez et al., 2011; Mahady et al., 2011; Lomonaco et al., 2013), they were found to have less beneficial effects than rosiglitazone and glitazars on steatotic HepaRG cells. Indeed, despite their effectiveness in animal models (Tanaka et al., 2003; George and Liddle, 2008) PPAR $\alpha$ agonists have been disappointing in clinical trials. Bezafibrate has been reported to decrease hepatic steatosis and to increase expression of enzymes involved in FAO in mice (Nagasawa et al., 2006). For this drug, an involvement of PPAR $\beta / \delta$ is likely since activation of PPAR $\beta / \delta$ has also been reported to deplete lipid accumulation in mice (Wang et $a l ., 2003)$. By contrast, no impact on steatosis was obtained in patients after a 12-monthtreatment with clofibrate, another PPAR $\alpha$ agonist (Laurin et al., 1996). 
To better understand the mechanisms involved in the decrease of triglycerides content by PPAR agonists, expression of several genes involved in the main lipid metabolism functions was analysed. Since HepaRG cells were simultaneously exposed to OA and PPAR agonists, both pro-steatogenic and anti-steatogenic effects could be expected at the level of gene expression. The PPAR $\gamma$ agonist rosiglitazone and especially the dual PPAR agonist muraglitazar, which were the most potent compounds in reducing triglycerides content and inducing FAO in HepaRG cells also exerted the highest effects on deregulation of several key genes involved in lipid metabolism, including ACOX1, CPT1A, PPARA, PPARG, ADFP, PLIN4, LXRA, FXR and CAR. ACOX1 and CPT1A were dramatically up-regulated from 1day and remained expressed at high levels after 14-day treatment, especially with muraglitazar. ACOX1 enzyme, which is the first and rate-limiting enzyme of the peroxisomal $\beta$-oxidation pathway, plays a major role in the development of hepatic steatosis in rodents (Fan et al., 1996) and re-expression of ACOX1 isoform in $\mathrm{ACOX}^{-/-}$mice leads to reversal of hepatic steatosis (Vluggens et al., 2010). Peroxisomal $\beta$-oxidation is critical for the degradation of very long chain fatty acids that are not able to be degraded by the mitochondrial $\beta$-oxidation system. After shortening of these long-chain fatty acids, they are taken-up by the mitochondrial system, in which CPT1A is a major enzyme involved.

Transcriptomic modulations were confirmed by investigation of FAO activity after treatments of OA-overloaded HepaRG cells with PPAR agonists. Indeed FAO activity was increased after 14-day repeat treatment with all PPAR agonists, especially with muraglitazar, supporting the view that the diminution of steatosis in HepaRG cells might be explained by a sustained activation of FAO.

It is noteworthy that expression of genes encoding perilipin proteins, such as ADFP and PLIN4, implicated in lipid droplet formation was also up-regulated by PPAR agonist treatment. These two proteins are well known to coat the lipid droplets, and consequently they represent a marker of steatosis. Consequently, a decreased expression of ADFP and PLIN4 would have been expected in cells treated with PPAR agonists due to the reversal of steatosis and diminution of triglycerides content. However, according to recent data, these two perilipin proteins are thought to protect non adipose cells, such as liver cells, from the lipotoxicity of free fatty acids by vesicle formation (Borg et al., 2009; Simard et al., 2010). This could explain the persistent over-expression of those perilipin proteins in steatotic HepaRG cells. 
As emphasized above, muraglitazar was the most effective PPAR agonist to reverse steatosis in HepaRG hepatocytes overloaded with OA. Analysis of the deregulated genes including those encoding nuclear receptors, such as LXR $\alpha$, FXR and CAR, suggested that muraglitazar could reverse steatosis by modulation of expression of these genes. The absence of significant diminution of LXR $\alpha$ transcripts supported the view that muraglitazar had no direct effect on LXR $\alpha$ expression. However, activation and overexpression of FXR by this compound might result in inhibition of LXR $\alpha$ action, that in turn would lead to the diminution of LXR $\alpha$ target genes, such as SREBP1-c, with as a consequence a reduction of de novo lipogenesis in accordance with diverse recent studies showing that FXR activation could reduce LXR $\alpha$ effect and then down-regulate de novo lipogenesis (Watanabe et al., 2004; Zhang et al., 2004).

In addition, muraglitazar still induced CAR expression after a 14-day treatment that could also result in down-regulation of SREBP1c and stimulate the FAO pathway (Dong et al., 2009). This result could be an explanation why muraglitazar was the most potent PPAR agonist in reducing steatosis in HepaRG cells. Further investigations of the precise effects of the different classes of PPAR agonists on nuclear receptors and the resulting alterations of lipid metabolism should allow better characterizing the mechanisms by which these agonists differentially reverse steatosis.

In summary, this study represents the first analysis of the effects of diverse PPAR agonists on the different PPAR subtypes in steatotic human hepatocytes after repeat treatment. Its brings a proof of concept that drug-induced reversal of steatosis in man could be evaluated in vitro before conducting long-term and costly in vivo studies in animals and patients. In addition, our results show that although all PPAR agonists were effective dual PPAR $\alpha / \gamma$ and PPAR $\gamma$ agonists appeared to be the most potent inducers of FAO and the most effective in reducing triglyceride accumulation in OA-overloaded HepaRG hepatocytes. These data give new insights in the effects of PPAR agonists on human hepatic steatosis and suggest that the HepaRG cell line appears suitable for a better understanding of the mechanisms involved in steatosis reversal, which is essential for the future development of novel and efficient therapeutic PPAR agonist agents for the treatment of NAFLD. 


\section{REFERENCES}

Aninat, C., Piton, A., Glaise, D., Le Charpentier, T., Langouet, S., Morel, F., Guguen-Guillouzo, C., and Guillouzo, A. (2006). Expression of cytochromes P450, conjugating enzymes and nuclear receptors in human hepatoma HepaRG cells. Drug Metab Dispos 34, 75-83.

Antherieu, S., Chesne, C., Li, R., Camus, S., Lahoz, A., Picazo, L., Turpeinen, M., Tolonen, A., Uusitalo, J., Guguen-Guillouzo, C., and Guillouzo, A. (2010). Stable expression, activity, and inducibility of cytochromes P450 in differentiated HepaRG cells. Drug Metab Dispos 38, 516-525.

Antherieu, S., Rogue, A., Fromenty, B., Guillouzo, A., and Robin, M. A. (2011). Induction of vesicular steatosis by amiodarone and tetracycline is associated with up-regulation of lipogenic genes in HepaRG cells. Hepatology 53, 1895-1905.

Balas, B., Belfort, R., Harrison, S. A., Darland, C., Finch, J., Schenker, S., Gastaldelli, A., and Cusi, K. (2007). Pioglitazone treatment increases whole body fat but not total body water in patients with non-alcoholic steatohepatitis. J Hepatol 47, 565-570.

Barish, G. D., Narkar, V. A., and Evans, R. M. (2006). PPAR delta: a dagger in the heart of the metabolic syndrome. J Clin Invest 116, 590-597.

Belfort, R., Harrison, S. A., Brown, K., Darland, C., Finch, J., Hardies, J., Balas, B., Gastaldelli, A., Tio, F., Pulcini, J., Berria, R., Ma, J. Z., Dwivedi, S., Havranek, R., Fincke, C., DeFronzo, R., Bannayan, G. A., Schenker, S., and Cusi, K. (2006). A placebo-controlled trial of pioglitazone in subjects with nonalcoholic steatohepatitis. N Engl J Med 355, 2297-2307.

Borg, J., Klint, C., Wierup, N., Strom, K., Larsson, S., Sundler, F., Lupi, R., Marchetti, P., Xu, G., Kimmel, A., Londos, C., and Holm, C. (2009). Perilipin is present in islets of Langerhans and protects against lipotoxicity when overexpressed in the beta-cell line INS-1. Endocrinology 150, 30493057.

Caldwell, S., and Argo, C. (2010). The natural history of non-alcoholic fatty liver disease. Dig Dis 28, 162-168.

Cerec, V., Glaise, D., Garnier, D., Morosan, S., Turlin, B., Drenou, B., Gripon, P., Kremsdorf, D., Guguen-Guillouzo, C., and Corlu, A. (2007). Transdifferentiation of hepatocyte-like cells from the human hepatoma HepaRG cell line through bipotent progenitor. Hepatology 45, 957-967.

Chen, H., Dardik, B., Qiu, L., Ren, X., Caplan, S. L., Burkey, B., Boettcher, B. R., and Gromada, J. (2010). Cevoglitazar, a novel peroxisome proliferator-activated receptor-alpha/gamma dual agonist, potently reduces food intake and body weight in obese mice and cynomolgus monkeys. Endocrinology 151, 3115-3124.

Deehan, R., Maerz-Weiss, P., Catlett, N. L., Steiner, G., Wong, B., Wright, M. B., Blander, G., Elliston, K. O., Ladd, W., Bobadilla, M., Mizrahi, J., Haefliger, C., and Edgar, A. (2012). Comparative transcriptional network modeling of three PPAR-alpha/gamma co-agonists reveals distinct metabolic gene signatures in primary human hepatocytes. PLoS One 7, e35012.

Desvergne, B., Michalik, L., and Wahli, W. (2006). Transcriptional regulation of metabolism. Physiol Rev 86, 465-514.

Dong, B., Saha, P. K., Huang, W., Chen, W., Abu-Elheiga, L. A., Wakil, S. J., Stevens, R. D., Ilkayeva, O., Newgard, C. B., Chan, L., and Moore, D. D. (2009). Activation of nuclear receptor CAR ameliorates diabetes and fatty liver disease. Proc Natl Acad Sci U S A 106, 18831-18836.

Ericsson, H., Hamren, B., Bergstrand, S., Elebring, M., Fryklund, L., Heijer, M., and Ohman, K. P. (2004). Pharmacokinetics and metabolism of tesaglitazar, a novel dual-acting peroxisome proliferator-activated receptor alpha/gamma agonist, after a single oral and intravenous dose in humans. Drug Metab Dispos 32, 923-929.

Fan, C. Y., Pan, J., Chu, R., Lee, D., Kluckman, K. D., Usuda, N., Singh, I., Yeldandi, A. V., Rao, M. S., Maeda, N., and Reddy, J. K. (1996). Targeted disruption of the peroxisomal fatty acyl-CoA oxidase gene: generation of a mouse model of pseudoneonatal adrenoleukodystrophy. Ann N Y Acad Sci 804, 530-541. 
Fernandez, M., Gastaldelli, A., Triplitt, C., Hardies, J., Casolaro, A., Petz, R., Tantiwong, P., Musi, N., Cersosimo, E., Ferrannini, E., and DeFronzo, R. A. (2011). Metabolic effects of muraglitazar in type 2 diabetic subjects. Diabetes Obes Metab 13, 893-902.

Fievet, C., Fruchart, J. C., and Staels, B. (2006). PPARalpha and PPARgamma dual agonists for the treatment of type 2 diabetes and the metabolic syndrome. Curr Opin Pharmacol 6, 606-614.

Fisch, C., Robin, M. A., Letteron, P., Fromenty, B., Berson, A., Renault, S., Chachaty, C., and Pessayre, D. (1996). Cell-generated nitric oxide inactivates rat hepatocyte mitochondria in vitro but reacts with hemoglobin in vivo. Gastroenterology 110, 210-220.

Gavrilova, O., Haluzik, M., Matsusue, K., Cutson, J. J., Johnson, L., Dietz, K. R., Nicol, C. J., Vinson, C., Gonzalez, F. J., and Reitman, M. L. (2003). Liver peroxisome proliferator-activated receptor gamma contributes to hepatic steatosis, triglyceride clearance, and regulation of body fat mass. J Biol Chem 278, 34268-34276.

George, J., and Liddle, C. (2008). Nonalcoholic fatty liver disease: pathogenesis and potential for nuclear receptors as therapeutic targets. Mol Pharm 5, 49-59.

Gripon, P., Rumin, S., Urban, S., Le Seyec, J., Glaise, D., Cannie, I., Guyomard, C., Lucas, J., Trepo, C., and Guguen-Guillouzo, C. (2002). Infection of a human hepatoma cell line by hepatitis B virus. Proc Natl Acad Sci U S A 99, 15655-15660.

Hamren, B., Ericsson, H., Samuelsson, O., and Karlsson, M. O. (2008). Mechanistic modelling of tesaglitazar pharmacokinetic data in subjects with various degrees of renal function-evidence of interconversion. Br J Clin Pharmacol 65, 855-863.

Kane, C. D., Francone, O. L., and Stevens, K. A. (2006). Differential regulation of the cynomolgus, human, and rat acyl-CoA oxidase promoters by PPARalpha. Gene 380, 84-94.

Kanebratt, K. P., and Andersson, T. B. (2008). Evaluation of HepaRG cells as an in vitro model for human drug metabolism studies. Drug Metab Dispos 36, 1444-1452.

Kim, J. B., Wright, H. M., Wright, M., and Spiegelman, B. M. (1998). ADD1/SREBP1 activates PPARgamma through the production of endogenous ligand. Proc Natl Acad Sci U S A 95, 4333-4337.

Laurin, J., Lindor, K. D., Crippin, J. S., Gossard, A., Gores, G. J., Ludwig, J., Rakela, J., and McGill, D. B. (1996). Ursodeoxycholic acid or clofibrate in the treatment of non-alcohol-induced steatohepatitis: a pilot study. Hepatology 23, 1464-1467.

Lim, H. J., Park, J. H., Lee, S., Choi, H. E., Lee, K. S., and Park, H. Y. (2009). PPARdelta ligand L-165041 ameliorates Western diet-induced hepatic lipid accumulation and inflammation in LDLR-/mice. Eur J Pharmacol 622, 45-51.

Lomonaco, R., Sunny, N. E., Bril, F., and Cusi, K. (2013). Nonalcoholic fatty liver disease: current issues and novel treatment approaches. Drugs 73, 1-14.

Mahady, S. E., Webster, A. C., Walker, S., Sanyal, A., and George, J. (2011). The role of thiazolidinediones in non-alcoholic steatohepatitis - a systematic review and meta analysis. $J$ Hepatol 55, 1383-1390.

Michalik, L., Auwerx, J., Berger, J. P., Chatterjee, V. K., Glass, C. K., Gonzalez, F. J., Grimaldi, P. A., Kadowaki, T., Lazar, M. A., O'Rahilly, S., Palmer, C. N., Plutzky, J., Reddy, J. K., Spiegelman, B. M., Staels, B., and Wahli, W. (2006). International Union of Pharmacology. LXI. Peroxisome proliferator-activated receptors. Pharmacol Rev 58, 726-741.

Miller, D. B., and Spence, J. D. (1998). Clinical pharmacokinetics of fibric acid derivatives (fibrates). Clin Pharmacokinet 34, 155-162.

Moran-Salvador, E., Lopez-Parra, M., Garcia-Alonso, V., Titos, E., Martinez-Clemente, M., GonzalezPeriz, A., Lopez-Vicario, C., Barak, Y., Arroyo, V., and Claria, J. (2011). Role for PPARgamma in obesity-induced hepatic steatosis as determined by hepatocyte- and macrophage-specific conditional knockouts. FASEB J 25, 2538-2550.

Moya, M., Gomez-Lechon, M. J., Castell, J. V., and Jover, R. (2010). Enhanced steatosis by nuclear receptor ligands: a study in cultured human hepatocytes and hepatoma cells with a characterized nuclear receptor expression profile. Chem Biol Interact 184, 376-387. 
Musso, G., Gambino, R., Cassader, M., and Pagano, G. (2010). A meta-analysis of randomized trials for the treatment of nonalcoholic fatty liver disease. Hepatology 52, 79-104.

Nagai, Y., Nishio, Y., Nakamura, T., Maegawa, H., Kikkawa, R., and Kashiwagi, A. (2002). Amelioration of high fructose-induced metabolic derangements by activation of PPARalpha. Am J Physiol Endocrinol Metab 282, E1180-1190.

Nagasawa, T., Inada, Y., Nakano, S., Tamura, T., Takahashi, T., Maruyama, K., Yamazaki, Y., Kuroda, J., and Shibata, N. (2006). Effects of bezafibrate, PPAR pan-agonist, and GW501516, PPARdelta agonist, on development of steatohepatitis in mice fed a methionine- and choline-deficient diet. Eur J Pharmacol 536, 182-191.

Ratziu, V., Giral, P., Jacqueminet, S., Charlotte, F., Hartemann-Heurtier, A., Serfaty, L., Podevin, P., Lacorte, J. M., Bernhardt, C., Bruckert, E., Grimaldi, A., and Poynard, T. (2008). Rosiglitazone for nonalcoholic steatohepatitis: one-year results of the randomized placebo-controlled Fatty Liver Improvement with Rosiglitazone Therapy (FLIRT) Trial. Gastroenterology 135, 100-110.

Reddy, J. K., and Hashimoto, T. (2001). Peroxisomal beta-oxidation and peroxisome proliferatoractivated receptor alpha: an adaptive metabolic system. Annu Rev Nutr 21, 193-230.

Rogue, A., Lambert, C., Josse, R., Antherieu, S., Spire, C., Claude, N., and Guillouzo, A. (2011). Comparative gene expression profiles induced by PPARgamma and PPARalpha/gamma agonists in human hepatocytes. PLoS One 6, e18816.

Rubin, C. J., Viraswami-Appanna, K., and Fiedorek, F. T. (2009). Efficacy and safety of muraglitazar: a double-blind, 24-week, dose-ranging study in patients with type 2 diabetes. Diab Vasc Dis Res 6, 205-215.

Scheen, A. J. (2007). Pharmacokinetic interactions with thiazolidinediones. Clin Pharmacokinet 46, 112.

Simard, J. R., Meshulam, T., Pillai, B. K., Kirber, M. T., Brunaldi, K., Xu, S., Pilch, P. F., and Hamilton, J. A. (2010). Caveolins sequester FA on the cytoplasmic leaflet of the plasma membrane, augment triglyceride formation, and protect cells from lipotoxicity. J Lipid Res 51, 914-922.

Tanaka, T., Yamamoto, J., Iwasaki, S., Asaba, H., Hamura, H., Ikeda, Y., Watanabe, M., Magoori, K., Ioka, R. X., Tachibana, K., Watanabe, Y., Uchiyama, Y., Sumi, K., Iguchi, H., Ito, S., Doi, T., Hamakubo, T., Naito, M., Auwerx, J., Yanagisawa, M., Kodama, T., and Sakai, J. (2003). Activation of peroxisome proliferator-activated receptor delta induces fatty acid betaoxidation in skeletal muscle and attenuates metabolic syndrome. Proc Natl Acad Sci U S A 100, 15924-15929.

Tonstad, S., Retterstol, K., Ose, L., Ohman, K. P., Lindberg, M. B., and Svensson, M. (2007). The dual peroxisome proliferator-activated receptor alpha/gamma agonist tesaglitazar further improves the lipid profile in dyslipidemic subjects treated with atorvastatin. Metabolism 56, 1285-1292.

Vluggens, A., Andreoletti, P., Viswakarma, N., Jia, Y., Matsumoto, K., Kulik, W., Khan, M., Huang, J., Guo, D., Yu, S., Sarkar, J., Singh, I., Rao, M. S., Wanders, R. J., Reddy, J. K., and CherkaouiMalki, M. (2010). Reversal of mouse Acyl-CoA oxidase 1 (ACOX1) null phenotype by human ACOX1b isoform [corrected]. Lab Invest 90, 696-708.

Wang, L., Zhang, D., Swaminathan, A., Xue, Y., Cheng, P. T., Wu, S., Mosqueda-Garcia, R., Aurang, C., Everett, D. W., and Humphreys, W. G. (2006). Glucuronidation as a major metabolic clearance pathway of 14c-labeled muraglitazar in humans: metabolic profiles in subjects with or without bile collection. Drug Metab Dispos 34, 427-439.

Wang, Y. X., Lee, C. H., Tiep, S., Yu, R. T., Ham, J., Kang, H., and Evans, R. M. (2003). Peroxisomeproliferator-activated receptor delta activates fat metabolism to prevent obesity. Cell 113, 159-170.

Watanabe, M., Houten, S. M., Wang, L., Moschetta, A., Mangelsdorf, D. J., Heyman, R. A., Moore, D. D., and Auwerx, J. (2004). Bile acids lower triglyceride levels via a pathway involving FXR, SHP, and SREBP-1c. J Clin Invest 113, 1408-1418. 
Ye, J. M., Frangioudakis, G., Iglesias, M. A., Furler, S. M., Ellis, B., Dzamko, N., Cooney, G. J., and Kraegen, E. W. (2002). Prior thiazolidinedione treatment preserves insulin sensitivity in normal rats during acute fatty acid elevation: role of the liver. Endocrinology 143, 4527-4535.

Zhang, B. C., Li, W. M., Li, X. K., Zhu, M. Y., Che, W. L., and Xu, Y. W. (2012). Tesaglitazar ameliorates non-alcoholic fatty liver disease and atherosclerosis development in diabetic low-density lipoprotein receptor-deficient mice. Exp Ther Med 4, 987-992.

Zhang, Y., Castellani, L. W., Sinal, C. J., Gonzalez, F. J., and Edwards, P. A. (2004). Peroxisome proliferator-activated receptor-gamma coactivator 1alpha (PGC-1alpha) regulates triglyceride metabolism by activation of the nuclear receptor FXR. Genes Dev 18, 157-169. 


\section{FIGURE LEGENDS}

Figure 1: Experimental design. Human HepaRG cells were cultured for two weeks (proliferative phase) with an appropriate medium as described in Material and Methods, and then the cells were transferred to the same medium supplemented with $2 \%$ DMSO in order to achieve cell differentiation. The cells were rendered steatotic after a $24 \mathrm{~h}$ treatment by oleic acid (OA); then they were treated for 1 day or 14 days with the PPAR agonists.

Figure 2: Determination of cell viability after PPAR agonist treatments in oleic acidoverloaded HepaRG cells. Cells were incubated for $24 \mathrm{~h}$ with $250 \mu \mathrm{M}$ oleic acid (OA) or the vehicle only (control) and then treated with PPAR agonists; i.e. $40 \mu \mathrm{M}$ troglitazone (TRO), 50 $\mu \mathrm{M}$ rosiglitazone (ROSI), $50 \mu \mathrm{M}$ muraglitazar (MURA), $300 \mu \mathrm{M}$ tesaglitazar (TESA), $25 \mu \mathrm{M}$ fenofibrate (FENO) or $25 \mu \mathrm{M}$ bezafibrate (BEZA) for 1 day or every 2-3 days for 14 days. Cytotoxicity was measured by the MTT colorimetric assay. Each point is the mean \pm SEM of three independent experiments. All results are expressed relative to untreated control, arbitrarily set at the value of $100 \%$; ns: no significant

Figure 3: Determination of neutral lipid accumulation by Oil Red $O$ staining after PPARs agonist treatments in oleic acid-overloaded HepaRG cells. (A) Cells were incubated for $24 \mathrm{~h}$ with $250 \mu \mathrm{M}$ oleic acid (OA) or the vehicle only (control) and then treated with PPAR agonists; i.e. $40 \mu \mathrm{M}$ troglitazone (TRO), $50 \mu \mathrm{M}$ rosiglitazone (ROSI), $50 \mu \mathrm{M}$ muraglitazar (MURA), $300 \mu \mathrm{M}$ tesaglitazar (TESA), $25 \mu \mathrm{M}$ fenofibrate (FENO) or $25 \mu \mathrm{M}$ bezafibrate (BEZA) for 1 day or every 2-3 days for 14 days. Neutral lipids (triglycerides and cholesterol esters) were stained by Oil Red $\mathrm{O}$ and the cells were photographed with phasecontrast microscope. Magnification 20X. (B) Quantification of Oil Red O pictures was realized by ImageJ software; areas of stained lipid droplets were determined for each condition ( 3 pictures per condition) and normalized by the areas of hepatocyte clusters. Each point is the mean \pm SEM of three independent experiments. All results are expressed relative to untreated control, arbitrarily set at the value of $100 \%$. $\# \mathrm{p}<0.05$ compared with control, $* p<0.05$ compared with OA treatment. 
Figure 4: Triglycerides quantification after PPAR agonist treatments in oleic acidoverloaded HepaRG cells. Cells were incubated for $24 \mathrm{~h}$ with $250 \mu \mathrm{M}$ oleic acid (OA) or the vehicle only (control) and then treated with PPAR agonists; i.e. $40 \mu \mathrm{M}$ troglitazone (TRO), 50 $\mu \mathrm{M}$ rosiglitazone (ROSI), $50 \mu \mathrm{M}$ muraglitazar (MURA), $300 \mu \mathrm{M}$ tesaglitazar (TESA), $25 \mu \mathrm{M}$ fenofibrate (FENO) or $25 \mu \mathrm{M}$ bezafibrate (BEZA) for 1 day or every 2-3 days for 14 days. Triglycerides (TG) levels were measured by spectrophotometry after chloroform/methanol extraction. Each point is the mean \pm SEM of three independent experiments. All results are expressed relative to untreated control, arbitrarily set at the value of $100 \%$. $\# \mathrm{p}<0.05$ compared with control, $* \mathrm{p}<0.05$ compared with OA treatment.

Figure 5: Determination of fatty acid oxidation after PPAR agonist treatments in oleic acid-overloaded HepaRG cells. Cells were incubated for $24 \mathrm{~h}$ with $250 \mu \mathrm{M}$ oleic acid (OA) or the vehicle only (control) and then treated with PPAR agonists; i.e. $40 \mu \mathrm{M}$ troglitazone (TRO), $50 \mu \mathrm{M}$ rosiglitazone (ROSI), $50 \mu \mathrm{M}$ muraglitazar (MURA), $300 \mu \mathrm{M}$ tesaglitazar (TESA), $25 \mu \mathrm{M}$ fenofibrate (FENO) or $25 \mu \mathrm{M}$ bezafibrate (BEZA) for 1 day or every 2-3 days for 14 days. Fatty acid oxidation (FAO) was evaluated by measuring $\left[{ }^{14} \mathrm{C}\right]$-labeled acidsoluble $\beta$-oxidation products generated by cells after a 90 minutes incubation with $\left[{ }^{14} \mathrm{C}\right]-$ palmitic acid. Each point is the mean \pm SEM of three independent experiments. All results are expressed relative to untreated control, arbitrarily set at the value of $100 \%$. $\# \mathrm{p}<0.05$ compared with control, ${ }^{*} \mathrm{p}<0.05$ compared with OA treatment. 


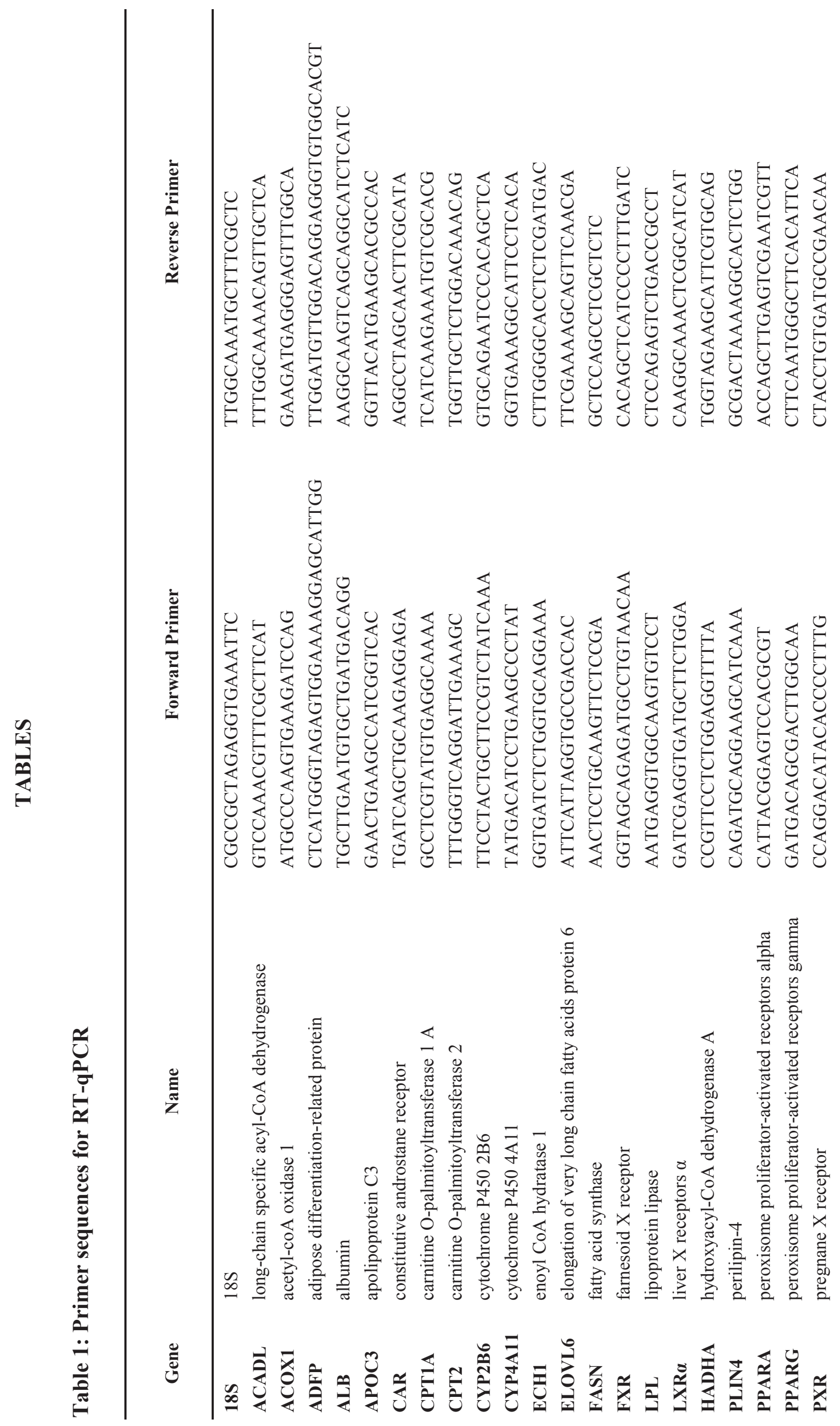




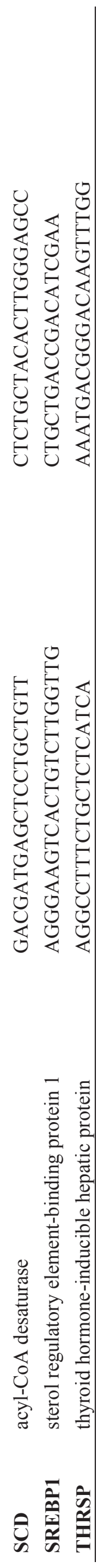




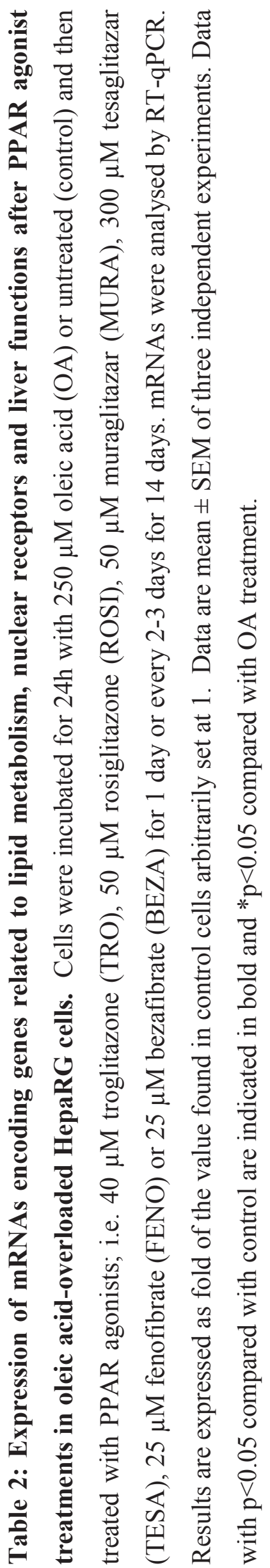




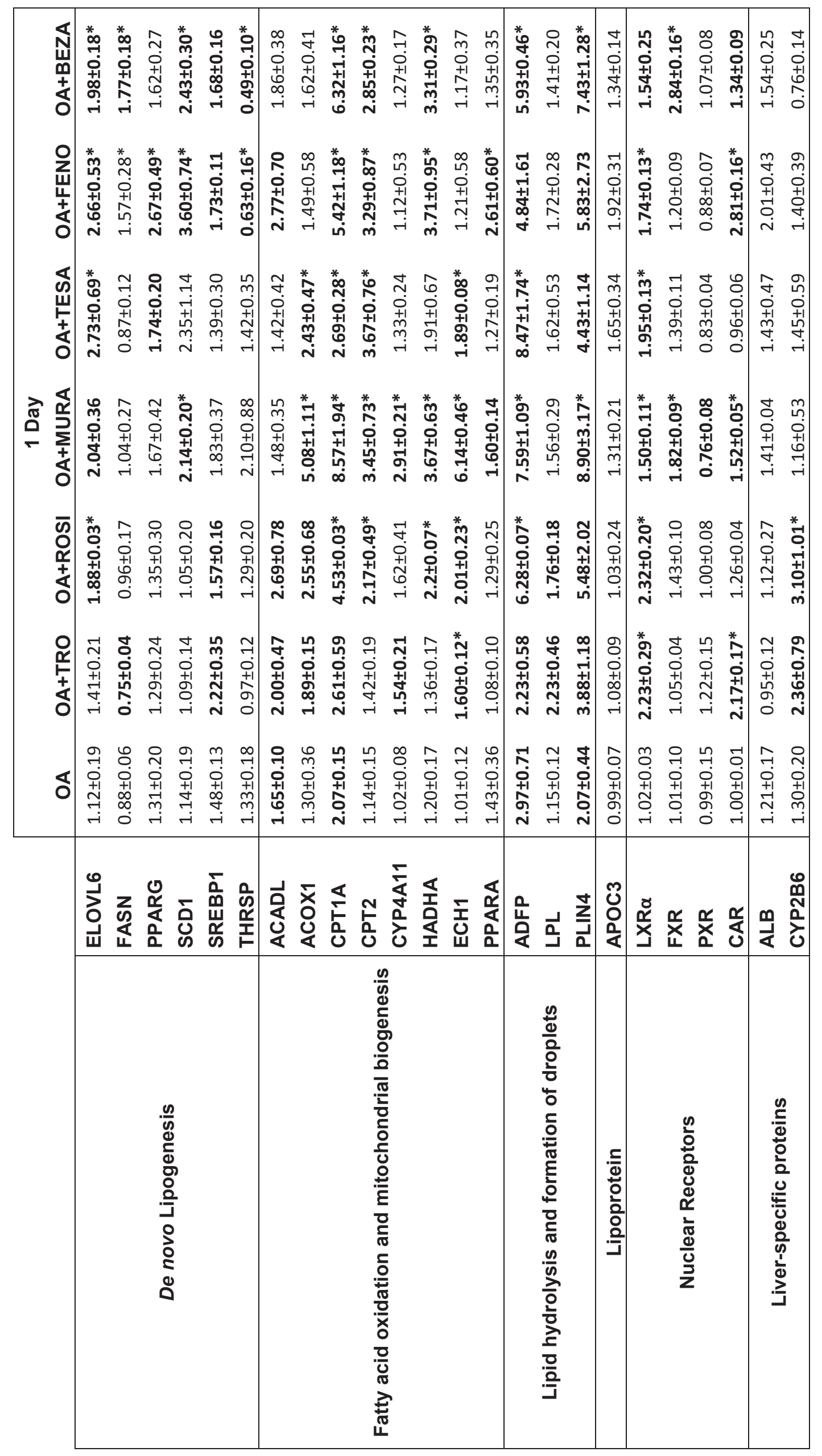




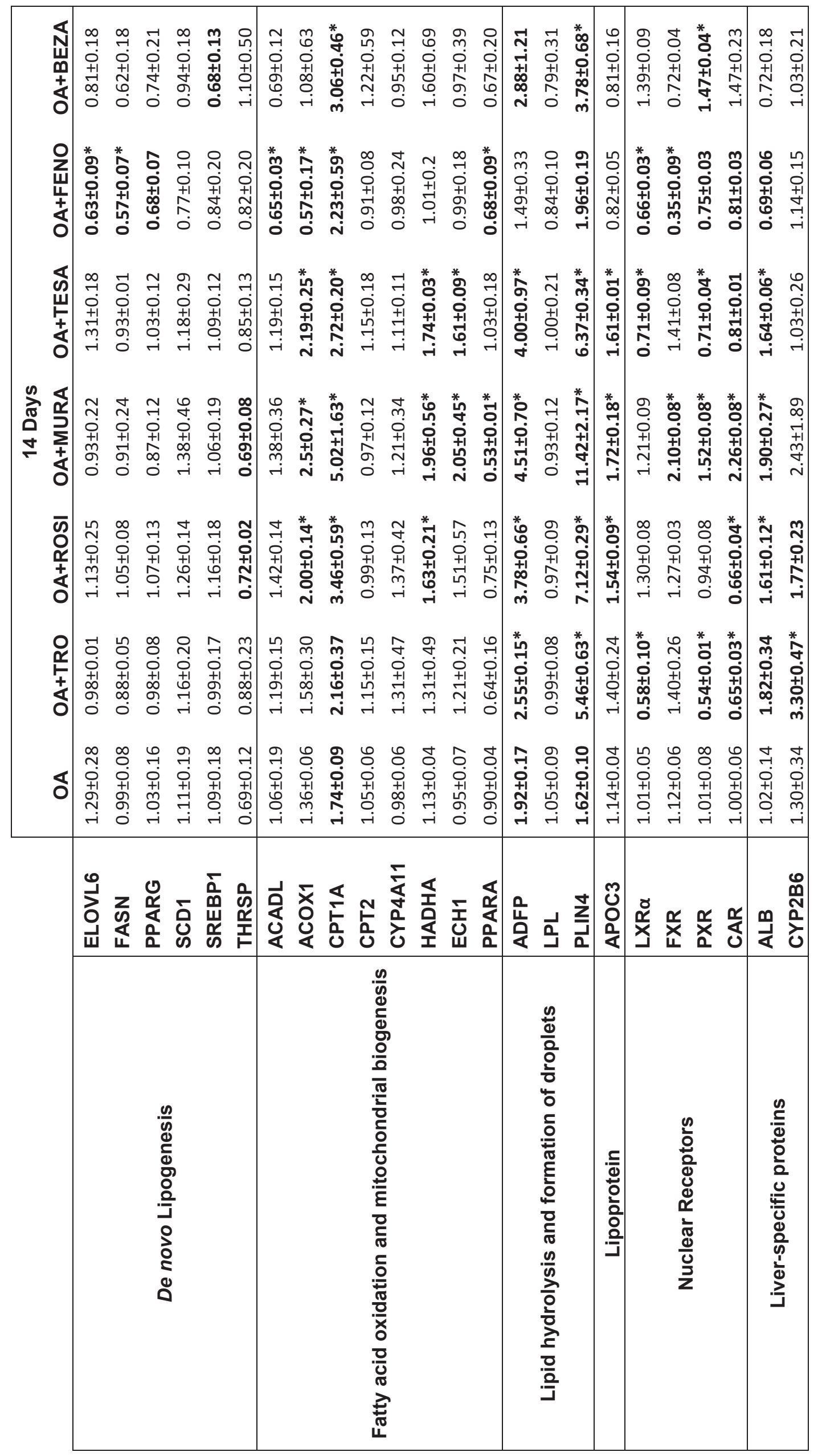




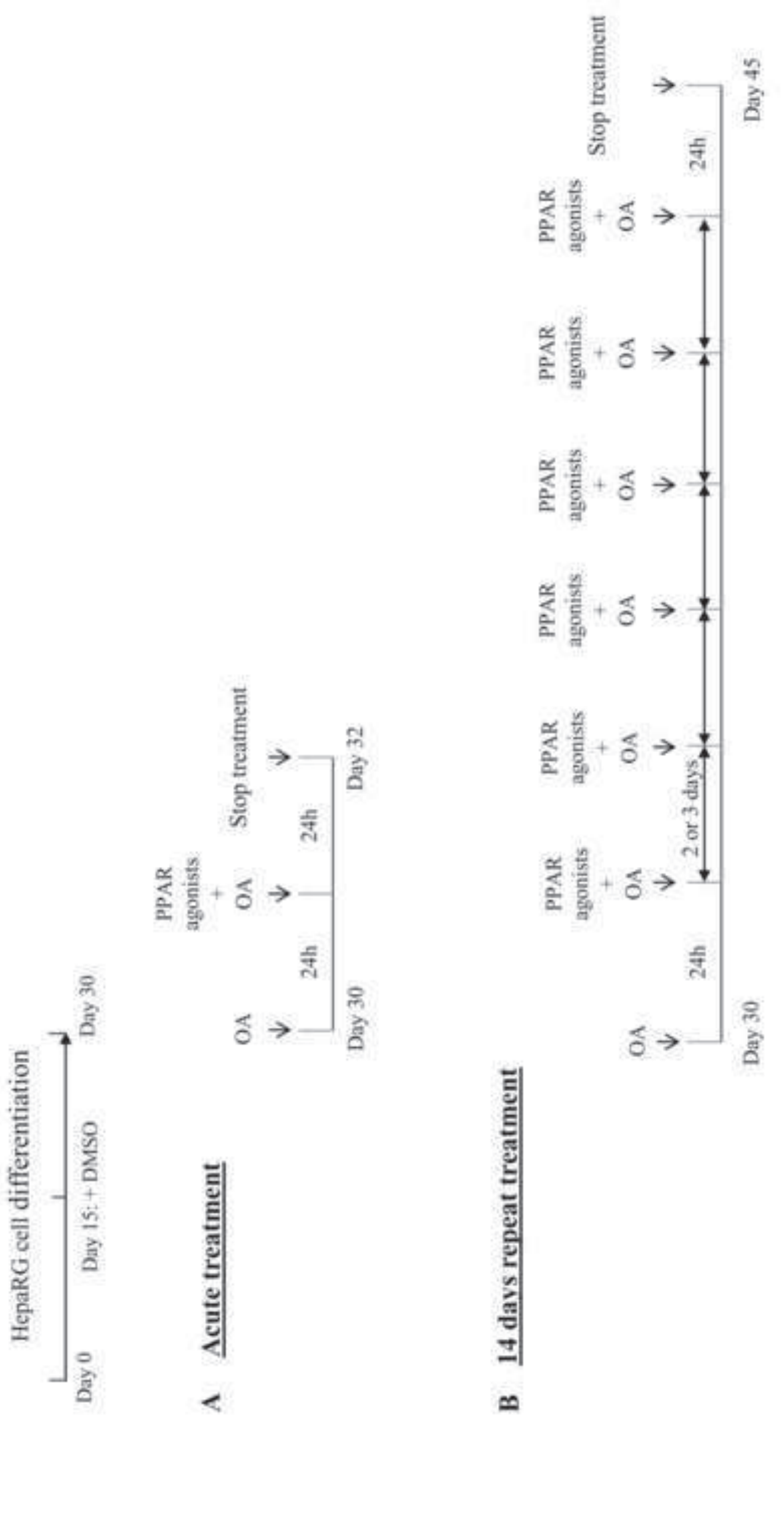



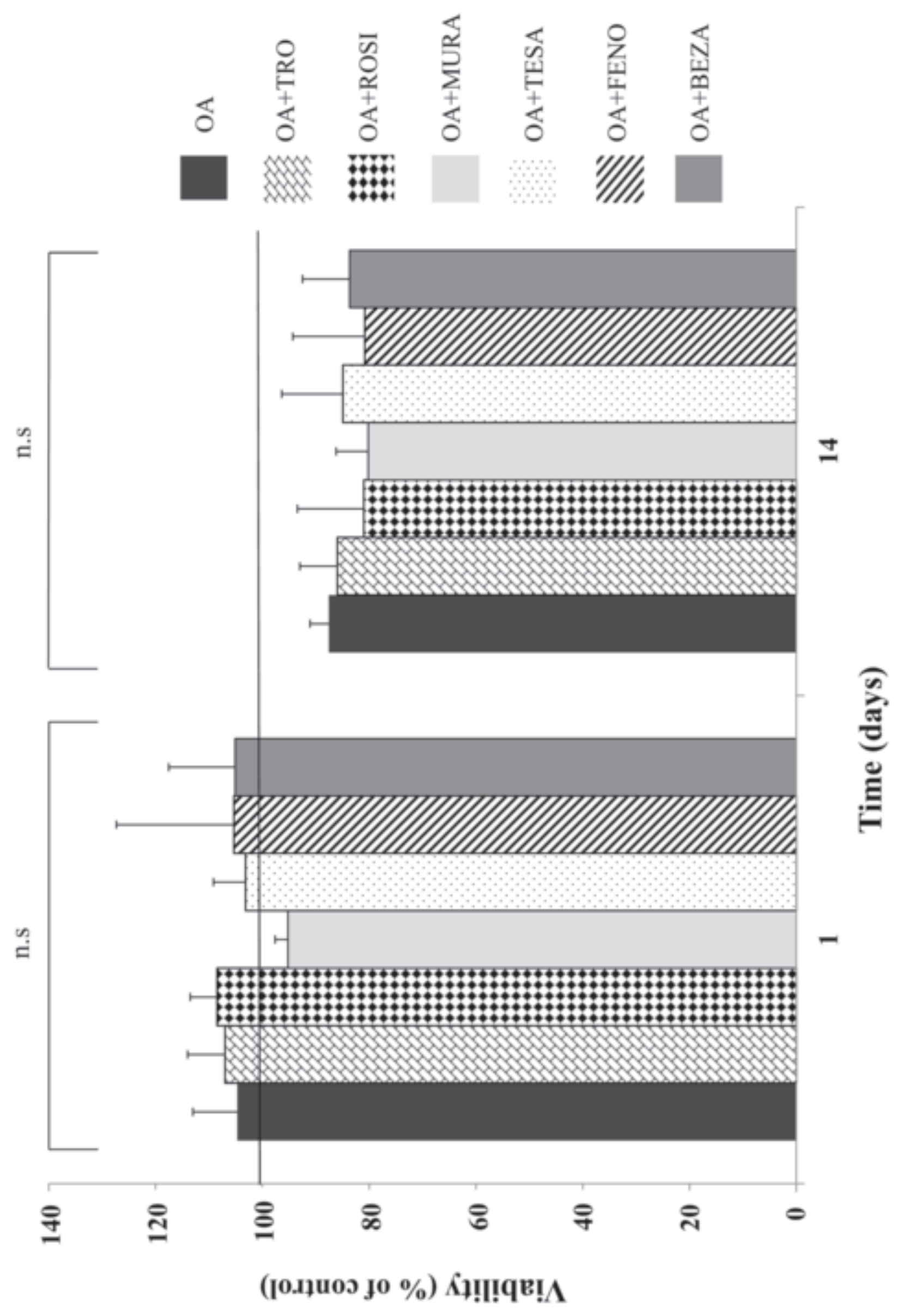

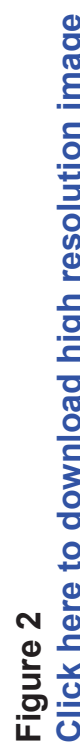


Figure 3-A

Click here to download high resolution image
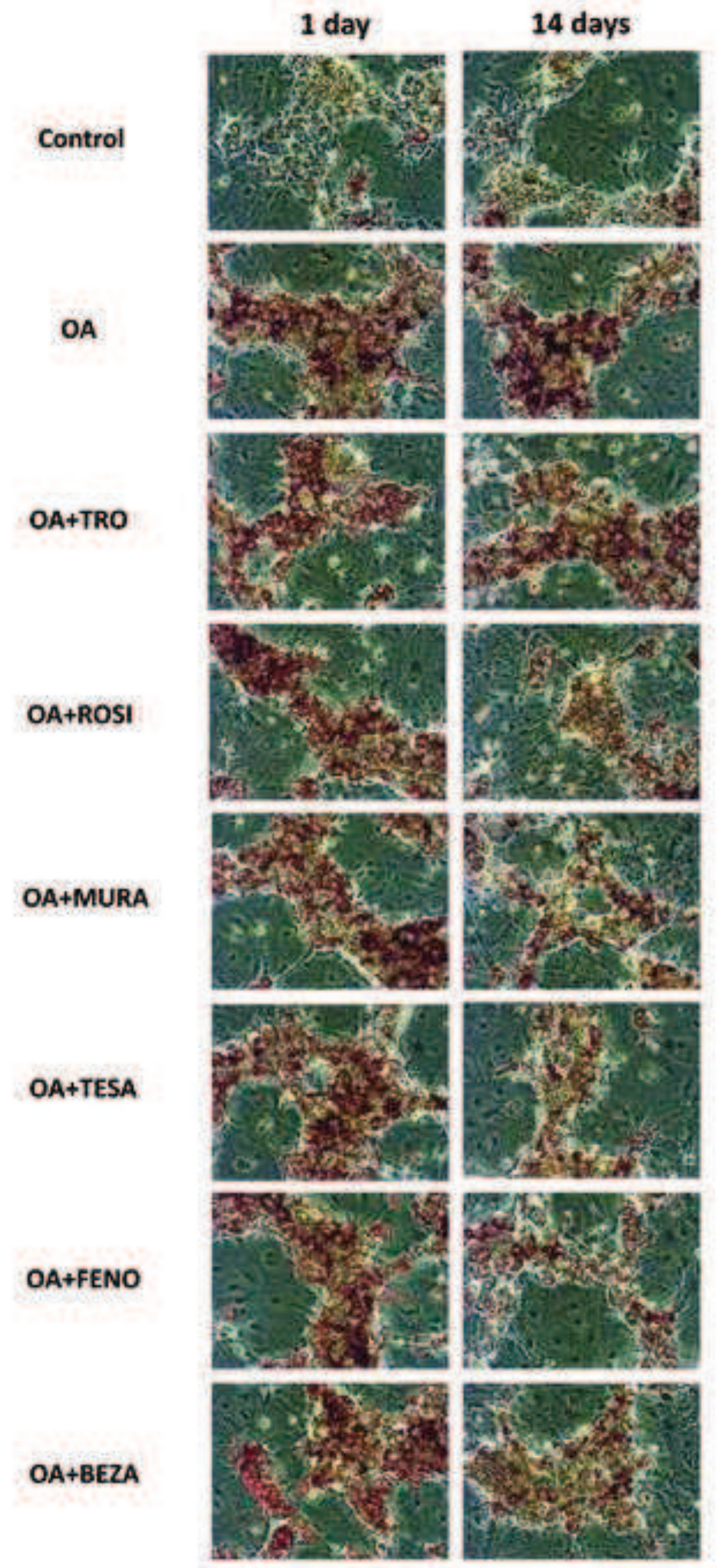


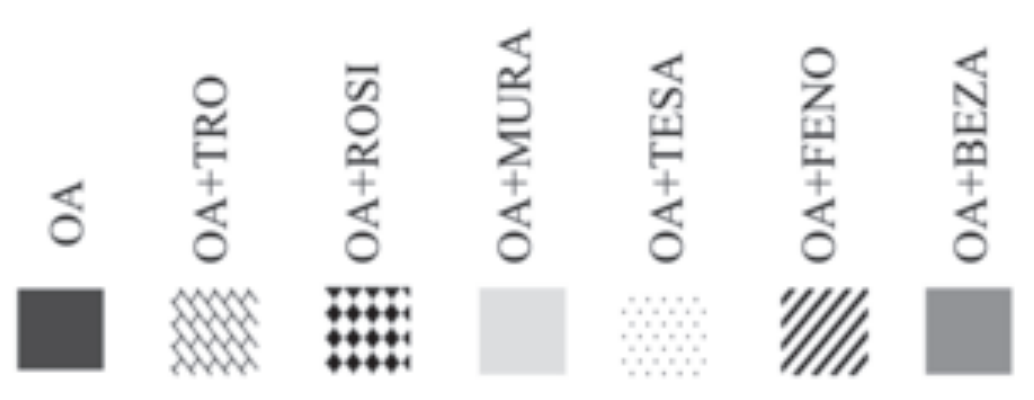

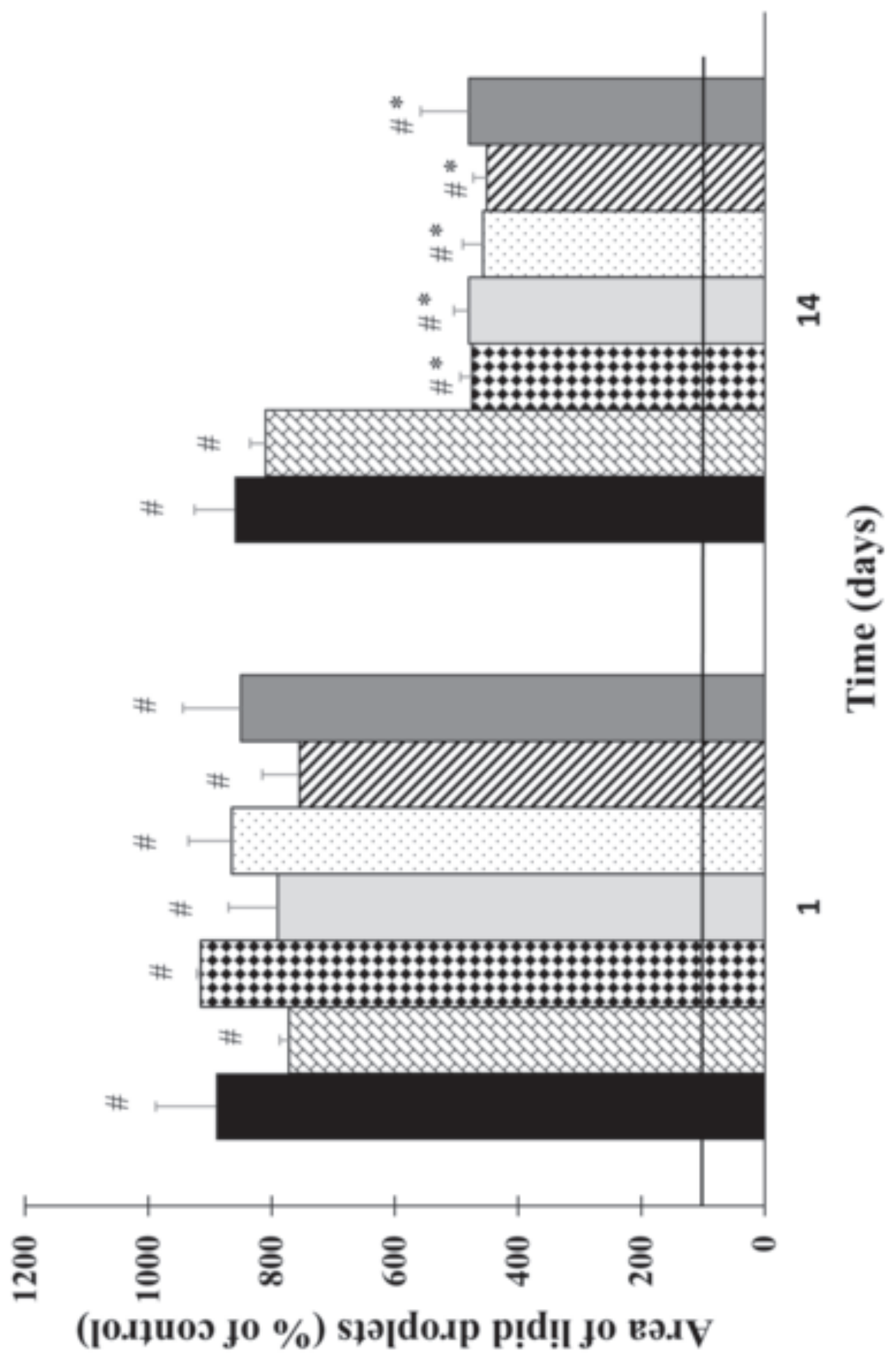

$m$

लें

은 

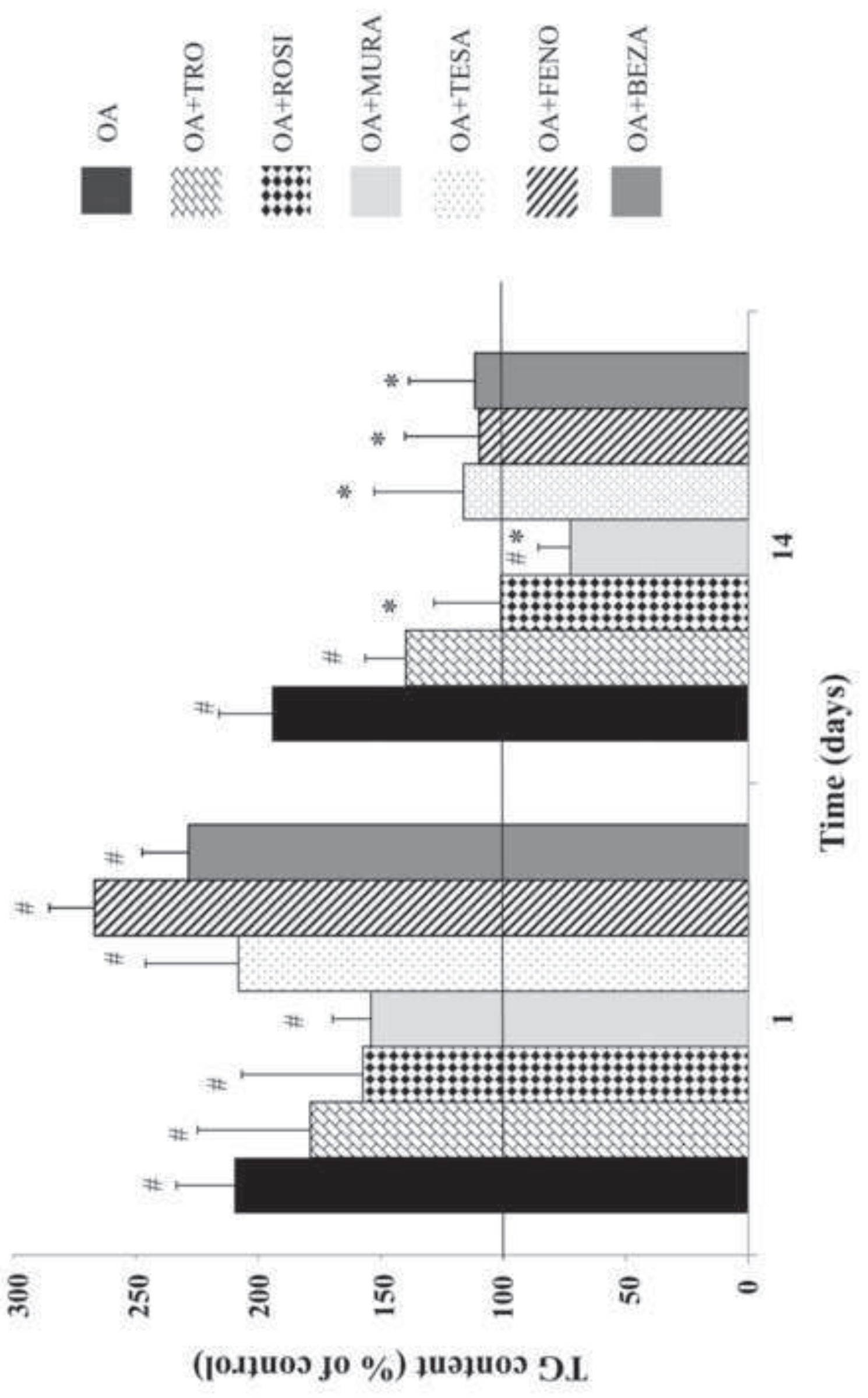

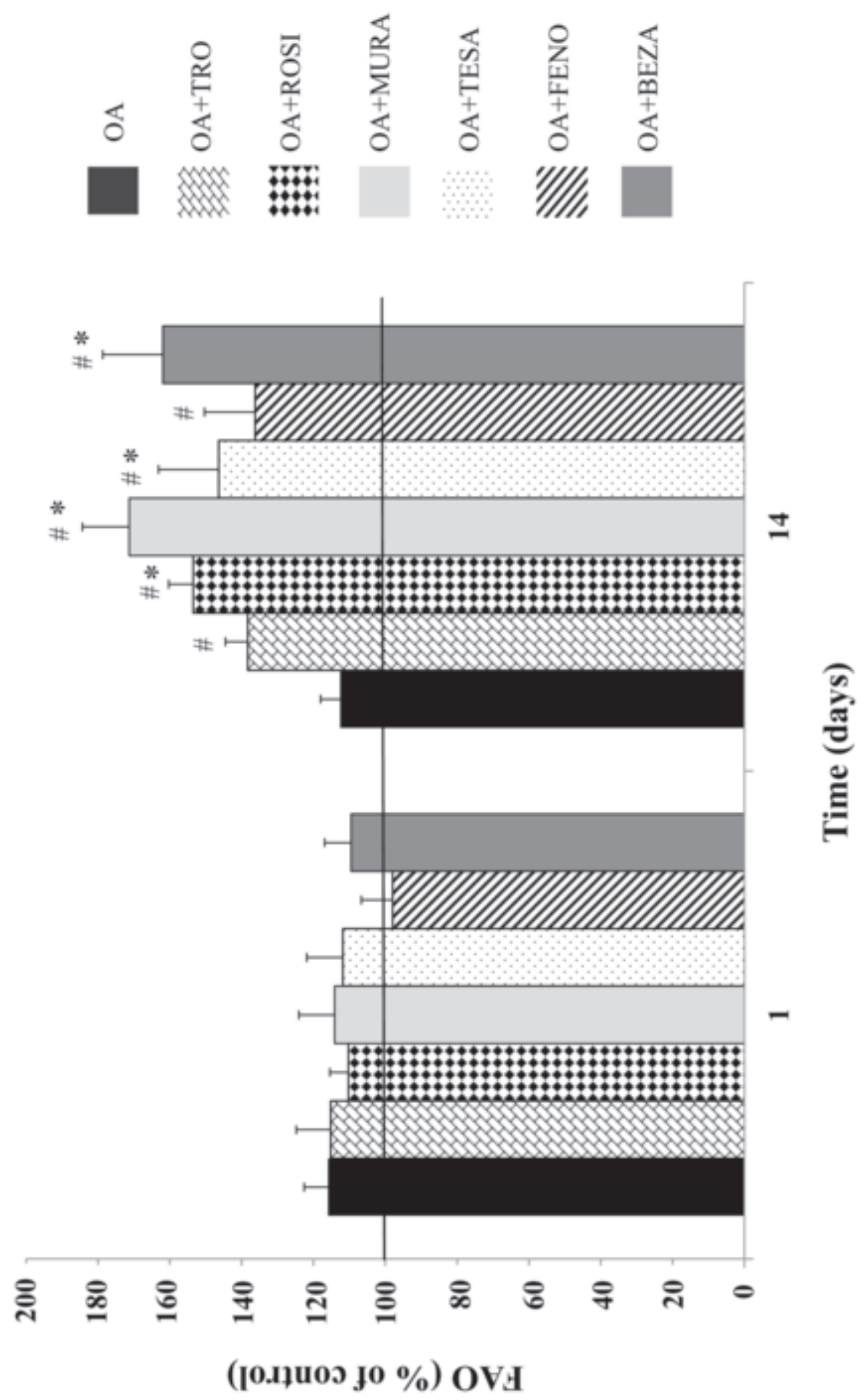

in

인

证 